\title{
A ROBOTIZÁlÁS ALAPJAI A GYÁRTÁSBAN ÉS SZERELÉSBEN
}

\author{
Kismihály János
}

\section{Összefoglalás}

Az ARMATURA szerelvénygyár nagysorozalban gyár ósszekơıðelemekel viz-, gáz-, gớz- és olajvezetékekhez. fûrdöszoba felszereléseket. nyomásszabályozókat. csapokat stb. A munkadarabok külónleges formáit és a termelés jellegé figyelembe véve indokolı a megmunkálókơzpontok és agregáıok használata. Ezek a szerszámgépek. a termelékenység maximális kihasználása érdekében. megkơvetelik az automatikus munkadarabadagolást. mely még egy megoldatlan probléma a cégnél. Hasonló a helyzet a szerelorészlcgen alkalmazo1ı célgépek esetében is melycket futószalag kơı óssze. Mindezcket figyelembe véve a dolgozat ismencti arokat a fo elveket. melyck betartára rendkivül fontos a robotizálás valamint az automatizálás csctén és bemutat egy elméleti robotizálı szerelö-tesıtelö rendszert külómbozơ tipusu csapok szerelésére, melyet kơzosen terveztünk a Mûszaki Egyelem szakembereivel.

\section{1. Általános problémák}

\subsection{Rugalmas gyártórendszerek jellemzõi}

Egy rugalmas gyártórendszer részére az u.n. minimális sorozatnagyság akár egy-egy munkadarab is lehet. Az l.ábrából a különféle rugalmasságú gyártóeszközök alkalmazási kritériumai olvashatók le.

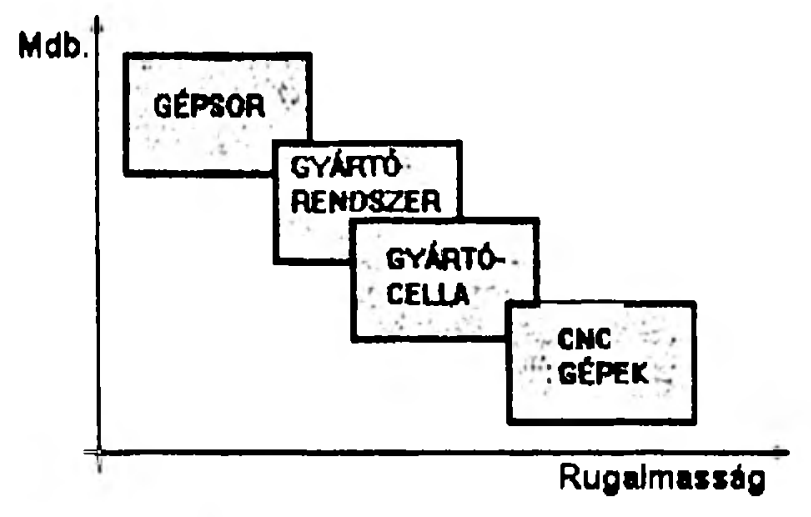

1.ábra. Különféle nugalmasságí gyártóeszkỏzók alkalmazási kritériumai.

Egy rugalmas gyártórendszer két szempontból lehet rugalmas:

-adott gyártási feladatra történõ átálláskor, -tetszõleges sorrendben érkezõ munkadarabok megmunkálására történõ átálláskor.

Fontosabb gazdaságossági feltételek:

-automatikus

gyártása egy

alkatrészcsaládnak,

-alkalmazkodás a piac igényeihez,

-a berendezés bõvitése leállás nélkül,

egyes elemek kiesésekor, azok feladatának automatikusan átvétele más elemek által,

A gazdaságos gyártás alappillérei:

-az NC ès CNC szerszámgépek rugalmasságának és termelékenységének kihasználása,

-átállási idõk csökkenése,

-a munkadarabok és szerszámok automatikus cseréje.

Autonóm szerszámgépeket azonos munkadarabok közepes és nagysorozatú gyártásnál alkalmazunk. A gépek között közbülsõ tárolás szükséges, az anyagmozgatás pedig kézi. 
Eltérõ munkadarabok gyártásánál, ahol a pontosság nem engedi meg a többszöri befogást a megmunkáló központ ajänlott. Már ebben az esetben is lehetõség van az automatikus munkadarabbeállitásra és a robotos kiszolgálásra. Még szigorúbb követelményeknél (többféle munkadarab, kis sorozat, a rendelés állandó változása) szükség van a gyártóeszközök rugalmasságára. A fõ probléma az, hogy minden munkadarabnál a megfelelõ program, készülèk és szerszám, a megfelelõ szerszámgépen legyen

\subsection{Munkadarab beállítás ipari robotokkal}

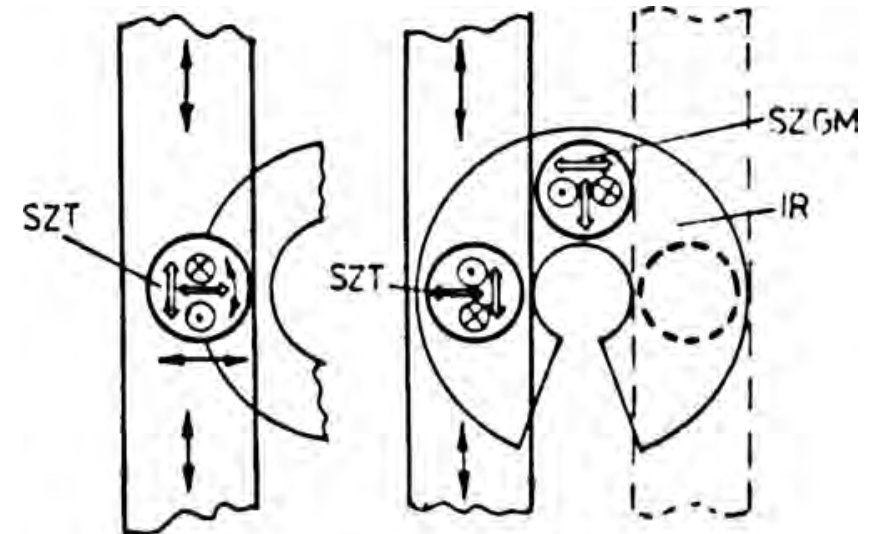

a,

b.

2.ábra. Szerszámgéptelepités: a SzGM és a SzT az IR munkaterében helyezkedik el.
Az ipari robotok (IR) által kiszolgált szerszámgépek (SzG) és ezek perifériài oly módon legyenek elhelyezve, hogy az anyagmozgatási feladatot az IR optimális mozgássorozattal tudja elvégezni. Sokféle IRSzG telepitési vázlat alakult ki. Legegyszerübb esetben a $\mathrm{SzG}$ olyan módon telepithetõ, hogy annak munkatere (SzGM), valamint a szállitótároló egység (SzT) az IR munkaterében legyen

\section{(2. ábra).}

Fogazógépeknél elterjedt, hogy egy átrakó egység (ÁE) segiti az IR-SzG kapcsolatot (3. ábra). A SzG nehezen hozzáférhetõ munkaterébe az $\dot{A} E$ nyúlik be. Az esztergáknál a portál típusú IR alkalmazása elōnyös, igy a robot teljes munkatere kihasználható. Szintén az ilyen típusú IR valósitják meg legkönyebben a ki-berakáshoz szükséges függöleges irányú mozgást (4. ábra).

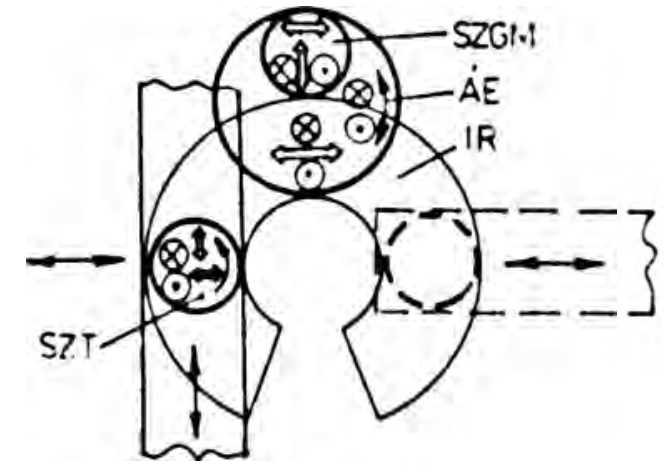

3.ábra. Átrakó eguség (ÁE) segiti az IR-SzG kapcsolatot.

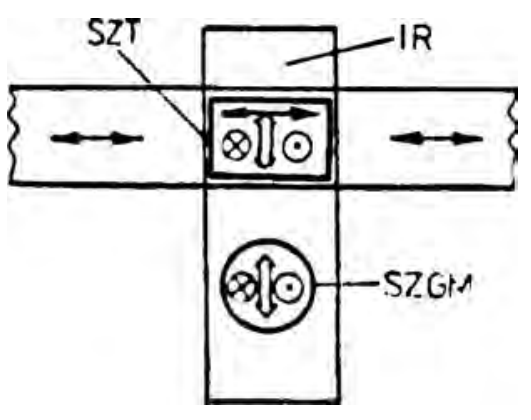

4.ábra. Poriál tipusí IR alkalmazása esztergáknál.

\section{Gyakorlati megvalósítások}

A robotok alkalmazása a romániai üzemekben még elég kezdeti szakaszban van. Cégünknek kooperációs kapcsolata van a Kolozsvári Mûszaki Egyetem Gépgyártástechnológia Tanszékével, melynek eredményeként jött létre a $S$. ábrán látható csap automatikus szerelésénak teve. Az automatikus szerelõsor alegysegei a 6 . ábra szerint: 


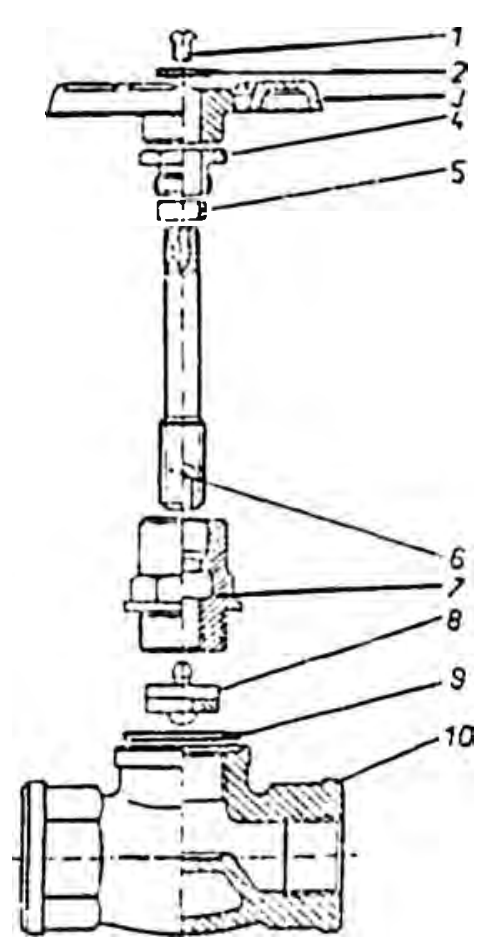

5.ábra. Az E8HM83 -as csap. 1-csavar, 2-alátél, 3-kerék, 4szoritócsavar, 5-lömszelence, 6 . orsó, 7-felsö-rész. 8-szelep. 9 tömités, 10-csapház.

\section{L1, L2 - alrendszerek, \\ T1, T2 - munkaállomás,}

TL1, TL2 - szállitószalag;

R1...R6 - ipari robotok;

DA1...DA8 - rezgõ adagolók;

DF1, DF8 - csavarozó készülékek;

P1, P2 - préselō készülékek;

DM - speciális préselõ készülék;

S1, S2 - tesztelõ munkaállomások,

DP1, DP2 - bemenetel/kimenetel;

A szerelõrendszer, a szilárdság- és záráspróbán kivül telyesen automatizált. Ezen a két munkahelyen egy-egy operátorra van szükség, aki felügyeli és irányitja a tesztelõ készülèket. Gazdasági okok miatt a terv gyakorlati része nem valósult meg. Tekintettel a jelenlegi gazdasági helyzetre a gyár a mai napig sem rendelkezik azon pénzügyi forrásokkal, melyek a terv kivitelezését lehetõvé tenné. A másik felmerülõ probléma az, hogy annak ellenére, hogy újraterveztük a termék összes elemét a robotizált szerelés céljainak megfelelōen, a létezõ megmunkálógépek pontossága nem elégiti ki az automatikus szereléshez szükségeset.

Összehasonlitva a jelenlegi- és a tervezett szerelõrendszert, a mûveletelemek sorrendjét az alkalmatott munkahelyekkel együtt az 1 . táblázat foglalja össze.

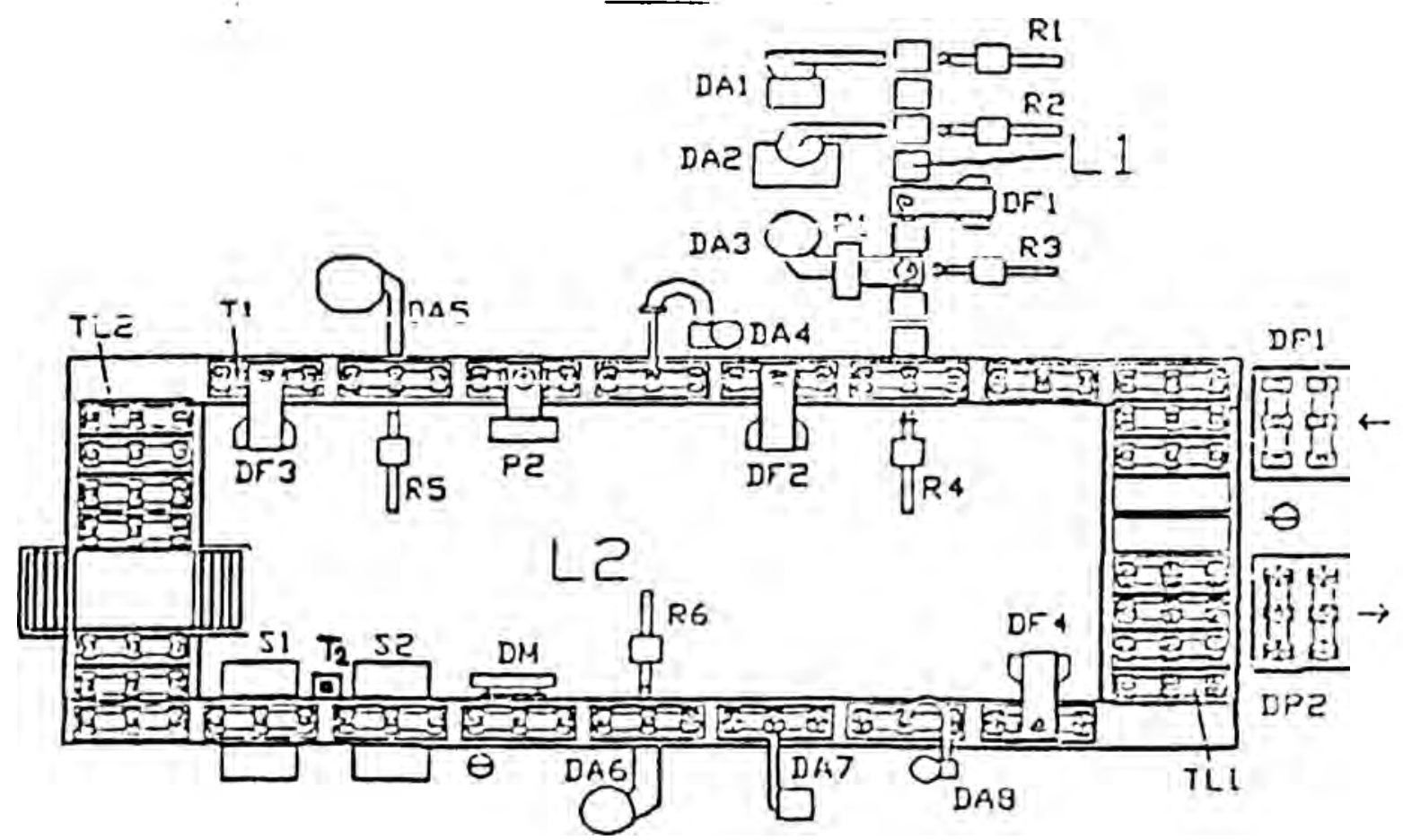

6.ábra. Az E8HM83-as tipusú csapok aulomatizált szerelörendszere. 
1. Táblázat

\begin{tabular}{|c|c|c|c|}
\hline $\begin{array}{l}\text { SOR- } \\
\text { SZÁM }\end{array}$ & MŪVELETELEM & $\begin{array}{l}\text { UJ TECHNO- } \\
\text { LOGIA }\end{array}$ & $\begin{array}{l}\text { JELENLEGI } \\
\text { TECHNOLÓGIA }\end{array}$ \\
\hline 1. & Csapház adagolása & $\mathrm{DPl}$ & - \\
\hline 2. & Orsó adagolása & $\mathrm{DA2}$ & - \\
\hline 3. & Orsó zsírozása & RI & kézi \\
\hline 4. & Felsö-rész adagolása & DA2 & - \\
\hline 5. & Orsó behelyezése a felsỏ-részbe & $\mathrm{R} 2$ & kézi \\
\hline 6. & Orsó becsavaràsa és peremezése & DF2 & csavarókészullék \\
\hline 7. & Szelep adagolása & DA3 & - \\
\hline 8. & Szelep bepreselése az orsóba & R3 & prés \\
\hline 9. & Tơmités ráhclyezèse a felsō-rés7.re & R4 & kézi \\
\hline 10. & Felsð-rćsz becsavarása a csaphárba & $\mathrm{DF} 2$ & csavarókćsrü̈lck \\
\hline 11. & Tóms zclence ráhúzása a $\angle$ orsóra & DA4 & ké $\angle i$ \\
\hline 12. & Tomszelence préselése a felsō-rćszbe & P2 & - \\
\hline 13. & Szoritócsavar adagolása & DA5 & - \\
\hline 14. & Szoritócsavar ráhúzása az orsóra & R5 & kézi \\
\hline 15 & Szoritócsavar becsavarása & DF3 & csavarókészullék \\
\hline 16. & Csap zárása & $\mathrm{TI}$ & csavarókészülék \\
\hline 17. & Atrakás & TL2 & konténer \\
\hline 18. & Záráspróba & $\mathrm{SI}$ & próbapad \\
\hline 19. & Csap nvitása & $\mathrm{T} 2$ & kéai \\
\hline 20. & Szilárdsági próba & S2 & próbapad \\
\hline 21. & Csap zárása & $\mathrm{DM}$ & kézi \\
\hline 22. & Kerćk adagolás & DA6 & - \\
\hline 23. & Kerék ráhúzása az orsóra & $\mathrm{R} 6$ & kézi \\
\hline 24. & Alátét adagolása & DA7 & - \\
\hline 25. & Csavar adagolása & DA8 & - \\
\hline 26. & Csavar becsavarása & DF4 & csayarókészülék \\
\hline 27. & Szerelt csapok átrakása & TLI & - \\
\hline 28. & Konténerbe rakás & DP2 & kézi \\
\hline
\end{tabular}

\section{Irodalom:}

[1] GYENGE, CS., BILC, N..Education and research activities in the field of robotics at the Faculty of Machine Building, Technical University of ClujNapoca. RAA'94, Bled, Slovenia, july 7-9.

[2] GYENGE, CS., KISMIHÁLY, J., KLEMENTIS,O.: Továbbfejlesztett algoritmus és számitógépes program az optimális mûveleti sorrend meghatározására. microCAD'95, Miskolc, 1995. febr.23-25.

[3] ARTS, G.: Rugalmas gyártócella rendszerek. BME, 1991.

KISMIHÁLY JÁNOS okleveles gépészmémök

ARMATURA RT Garii u., 19 sz., Kolozsvár

Tel. 64-13.27.37

Fax. 64-19.42.41 